\title{
Neoclassical Asset Pricing Tests in Sri Lanka: A Structural Empirical Review
}

\author{
N. S. Nanayakkara (Corresponding author) \\ Department of Finance, Faculty of Management Studies and Commerce \\ University of Sri Jayewardenepura, Sri Lanka \\ E-mail: neelangie@sjp.ac.lk \\ P. D. Nimal \\ Department of Finance, Faculty of Management Studies and Commerce \\ University of Sri Jayewardenepura, Sri Lanka \\ E-mail: pdnimal@sjp.ac.lk \\ Y. K. Weerakoon \\ Department of Finance, Faculty of Management Studies and Commerce \\ University of Sri Jayewardenepura, Sri Lanka \\ E-mail: weerakon@sjp.ac.lk
}

Received: April 1, $2020 \quad$ Accepted: Sep. 30, $2020 \quad$ Published: December 1, 2020

doi:10.5296/ajfa.v12i2.16782 URL: https://doi.org/10.5296/ajfa.v12i2.16782

\begin{abstract}
Neoclassical asset pricing models try to explain cross sectional variation in stock returns. This study critically reviews the findings of empirical investigations on neoclassical asset pricing models in the Colombo Stock Exchange (CSE), Sri Lanka. The study uses the structural empirical review (SER) methodology to capture a holistic view of empirical investigations carried out in the CSE from the year 1997 to 2017.

The pioneering Capital Asset Pricing Model (CAPM) (Sharpe, 1964; Lintner, 1965: Black, 1972) (SLB) states that market betas of stocks are sufficient to explain the cross sectional variation of stock returns. Alternatively there are multifactor models (Ross, 1976; Chen, 1986;
\end{abstract}


Fama and French, 1993, 2015; Cahart, 1997) that state stock returns are driven by multiple risk factors. Similar to other markets the findings on the SLB model are not consistent in the CSE. The Fama and French (1993) and the Cahart (1997) models are supported in the CSE which is consistent with other markets, but the explanatory powers of them are substantially low in the Sri Lankan context. Contrasting the findings of a significant impact of macroeconomic factors on stock returns in developed markets, the impact of them in the CSE are temporary.

The overall findings of the applicability of neoclassical asset pricing models in the CSE are inconsistent and inconclusive and the study identifies two reasons that may have contributed to such results. Firstly, it recognises that the inherent limitations of neoclassical asset pricing models may have affected the findings in the CSE. Secondly, it supports the argument that neoclassical models, as they are may not be applicable in emerging or frontier markets, thus they may need to be augmented with characteristics of such markets to make them more applicable.

Keywords: Neoclassical, Asset pricing, Returns, Factor models, Frontier market

JEL Classification: G12, G 15, G23 


\section{Introduction}

Neoclassical asset pricing models try to explain cross sectional variation of stock returns. The pioneering Capital Asset Pricing Model (CAPM) (Sharpe, 1964; Lintner, 1965; Black, 1972) (SLB) relates the stock return to a measure of its systematic risk, beta. According to the SLB model the expected returns of securities are a positive linear function of their market betas; and market betas suffice to describe the cross section of expected returns. Early studies support the linear relationship between average return and beta (Black, Jensen \& Scholes, 1972; Fama \& MacBeth, 1973). Subsequent empirical studies found anomalies to the SLB model that were not captured by beta alone (Basu, 1983; Banz, 1981; Stattman, 1980; Bhandari, 1988).

As Campbell (2000) reflects, the empirical anomalies and puzzles stimulates the development of new models in asset pricing, hence the inconclusive evidence on the SLB model led to the development of extensions to the SLB model (Mayers, 1972; Merton, 1973; Breeden, 1979) and other theoretical models such as Arbitrage Pricing Theory (APT) (Ross, 1976) for the variation of returns. On the other hand, atheoretical factor models were developed to fit the anomalous empirical evidence to the SLB model (Fama and French, 1993; 2015; Cahart, 1997). Though there is no consensus on a specific asset pricing model, neoclassical models are widely used in empirical research around the world.

There are studies that review neoclassical asset pricing tests in markets around the world. Dimson and Mussavian (1999) analyse the development of asset pricing theories, and highlight the fact that asset pricing literature is a coherent body of theory rather than a disjointed collection of publications. Campbell (2000) focuses on the interplay between theory and empirical work on the development of asset pricing literature for a period of twenty years. Celik (2012) provides a comprehensive review of asset pricing models and historical stream of empirical research from the year 1974 to 2005 . He states, factors that affect asset pricing vary through time yet the theoretical framework is still useful to incorporate the changing factors into pricing models.

The empirical reviews in asset pricing literature are centred on developed markets where neoclassical theories and empirical models were originated. Though these theories and models are later adopted in emerging and frontier markets it is hard to find studies that use systematic reviews that provide a holistic view of asset pricing tests in such markets. According to Berger et al. (2011) frontier markets have low integration with the world market and thereby offer significant diversification benefits to international investors. Therefore reviews of this nature will provide an insight to the frontier markets and shed light to the inquiry, whether asset pricing models that are originated in developed markets are applicable to emerging and frontier markets.

The Colombo Stock Exchange (CSE) in Sri Lanka is a frontier market established in 1985. It has around US\$ 20 billion market capitalisation with about 300 listed companies as of December 2017. Even though CSE is a contrastingly smaller market, tests of neoclassical asset pricing models are carried out in Sri Lanka similar to other emerging and frontier markets (Samarakoon, 1997; Nimal, 1997: Anuradha, 2008; Nanayakkara, 2008; Randeniya \& Wijerathna, 2012; Kongahawatte \& Nimal, 2015; Abeysekara \& Nimal, 2017). Therefore, the 
purpose of this study is to review the existing empirical asset pricing literature in the CSE to identify the extent to which neoclassical asset pricing tests can capture the cross sectional variation of stock returns in the market.

The study provides a comprehensive systematic literature review of empirical findings on neoclassical asset pricing tests, during the period from 1997 to 2017 in Sri Lanka. The study uses the structured empirical review (SER) methodology similar to Celik (2012) and Jesson and Lacey (2006). The study is significant in Sri Lankan context since it covers twenty years of empirical investigations on asset pricing tests in CSE. In the global context it will provide an insight to a frontier market and will be a pivotal point for the consideration of alternative approaches in asset pricing tests in such markets.

The remainder of this paper is structured as follows: Section 2, the literature review which includes a brief theoretical development and empirical findings of the neoclassical asset pricing models. Section 3 describes the structured empirical review (SER) methodology which is adopted in this study. Section 3.2 shows the classification and number of local studies selected for this review. Section 4 elaborates the findings of Sri Lankan studies with an overview of Sri Lankan investigations. Section 5 discusses the Sri Lankan findings in relation to the findings of other markets. Section 6 concludes the study with future direction for research.

\section{Literature Review}

Neoclassical asset pricing models are built upon the assumptions that; investors are rational, markets are highly efficient and investors exploit potential arbitrage opportunities (Dimson \& Mussavian, 1999). Markowitz (1952) portfolio theory and Tobin (1958) separation theorem led to the development of pioneering Capital Asset Pricing Model (CAPM) (Sharpe, 1964; Lintner, 1965; Black, 1972) (SLB). According to the SLB model; if all investors are single period mean variance optimisers, then the market portfolio is mean-variance efficient, which implies a positive beta return relationship between all assets and the market portfolio and market betas suffice to describe the cross section of stock returns (Fama \& French, 1992).

Mayers (1972) extends the one period two parameter SLB model to include non-marketable asset, human capital. The model assumes holding of specific marketable asset by an investor is partly determined by the relationship between returns on the assets and the payoffs on the specific non-marketable asset held by the investor (Fama \& Schwert, 1977). Merton (1973) develops an Intertemporal CAPM (ICAPM) with the assumption that time flows continuously rather than discretely. Breeden (1979) derives the Consumption CAPM (CCAPM) where, the single beta model in multi good, continuous time with uncertain consumption goods' prices and investment opportunities. Fabozzi and Francis (1978) test stability of beta over bull and bear markets, and finds that beta corresponding to bear market may be more appropriate measure of portfolio risk than the conventional single beta. Similarly Pettengill, Sundaram and Mathur (1995) test the conditional relationship between beta and return; it supports that there is a positive (negative) relationship between beta and stock returns during the periods of up (down) markets. 
Ross (1976) develops the Arbitrage Pricing Theory (APT) as an alternative theoretical explanation for variation of stock returns. APT points out that the SLB conclusion can also be reached; using an asymptotic no-arbitrage argument with the assumption that market portfolio is the only source of common, undiversifiable risk. Therefore, if there are several common factors that generate undiversifiable risk, then a multifactor model holds (Campbell, 2000). Chen et al. (1986) try to identify the specific macroeconomic variables to test the effect of economic forces within an APT (Ross, 1976) framework. The study selects the economic state factors which are expected to systematically influence the asset risk and finds that, though these macroeconomic variables are not exhaustive, the selected variables appear to outperform other potential pricing factors.

Early work by Black, Jensen and Scholes (1972); Fama and MacBeth (1973) were supportive to the SLB model, but subsequent studies find empirical contradictions to the SLB model. Banz (1981) reports the size effect, where small stocks have higher average excess returns which cannot be explained by the SLB model. Stattaman (1980); Rosenberg, Reid and Lanstein (1984) find that average return on stocks are positively related to the ratio of firm's book value of common equity (BE), to its market value (ME). Bhandari (1988) reports a positive relation between leverage and average return. Basu (1983) shows the earnings-price ratio (E/P) help explain the cross section of returns and Ball (1978) argues that E/P is a catch-all proxy for unnamed factors in expected returns. In 1993 based on the general pattern in stock returns Jegadeesh and Titman provide evidence on the momentum anomaly, where stocks with high/low returns over the past three to twelve months tend to outperform/underperform in the next three to twelve months.

Anomalous evidence to the SLB model led to the development of atheoritical multifactor models, where factors were chosen to fit the empirical evidence rather than its adherence to the theory. Fama and French (1992) use multifactor models and find that size, BE/ME absorb the apparent roles of leverage and E/P in average returns. Consistent with the findings, Fama and French (1993) introduce the three factor model (FF3FM) which includes the factors; the return on a broad market index, the excess return on a portfolio of small stocks over a portfolio of large stocks and the excess return on a portfolio of high BE/ME stocks over a portfolio of low BE/ME stocks. Cahart (1997) augments FF3FM with momentum factor (Jegadeesh \& Titman, 1993), to develop the Cahart four factor model (C4FM). In 2015, Fama and French relate profitability (Novy - Marx, 2013) and investment (Titman, Wei, \& Xie, 2004) factors to average returns and introduce the Fama and French five factor model (FF5FM) by augmenting profitability and investment factors to the existing FF3FM. According to Dempsey (2013) the trend of adding factors to better explain observed price behaviours has continued to dominate asset pricing theory.

The above asset pricing tests commonly use either cross sectional regression approach of Fama and MacBeth (1973) or the time series regression approach which centres on the GRS test of Gibbons, Ross and Shanken (GRS) (1989). According to Fama (2015) time series and cross sectional regression approaches to test asset pricing models are not competitors but complements. Therefore, tests in asset pricing include both time series and cross sectional analysis. 
Mehrling (2007) refers the SLB model as the revolutionary idea that runs through finance theory. The neoclassical asset pricing models have been continually and extensively tested in developed markets and they have been reviewed for their applicability and consistency. Similarly these models are tested in emerging and frontier markets, yet it is rare to find reviews that provide a holistic view of applicability and consistency of these models in the smaller markets. Therefore this study reviews twenty years of empirical investigations in neoclassical asset pricing models in the CSE to find whether these models provide similar results to that of developed markets.

\section{Methodology and Data}

\subsection{Structural Empirical Review (SER)}

The study uses Structural Empirical Review (SER) methodology to systematically review existing neoclassical asset pricing investigations in Sri Lanka. SER is specifically designed and developed to analyse research papers' evidence and interpreting results in a robust framework (Celik, 2012). According to Jesson and Lacey (2006) a systematic review is considered a quasiexperiment which derives results from data already described in published literature. It is a comprehensive and if possible a complete review of published articles selected to address a specific question. SER develops explicit statement of selection criteria to the studies that are to be reviewed (Kahn, Kunz, Kleijnen, \& Antes, 2003). This study uses SER for a comprehensive analysis of empirical evidence on neoclassical asset pricing tests in the CSE.

The study uses three search methods to identify and gather the relevant empirical investigations. The first search method was based on two selection/elimination criteria, which were developed on the evolution of neoclassical asset pricing models. The initial selection criterion was to search literature in the web based on key terms of asset pricing. The terms used with the word Sri Lanka were: asset pricing, CAPM, beta, anomalies, size, BE/ME, momentum, macroeconomic variables, APT, FF3FM, C4FM and FF5FM. They were used in different sets coupled with the word Sri Lanka. Thereafter, the study uses an elimination criterion that the relevant study should consider the CSE as a whole, and further that the investigation should be carried out during the period, 1997 to 2017. The search considers Sri Lankan and international journal articles and proceedings in academic conferences.

A second search method was developed based on the articles retrieved through the first method. The reference lists of the studies were explored to find studies which may not have been found in the first search. A third search method was to investigate Research Gate, Social Science Research Network (SSRN), and Google Scholar profiles of authors of the articles retrieved up to this stage, to find any studies that may not have been identified yet. 


\subsection{Data}

Initially the search collected 44 articles based on the key words identified through asset pricing literature. However, the applications of elimination criteria resulted 23 articles which are compared, contrasted, and critically reviewed in this study. The database of studies was coded based on the asset pricing model used in the study. If a study has investigated more than one model it was coded under each asset pricing model. Table 1 depicts the relevant code, the asset pricing model, the originators and number of studies reviewed in this study.

Table 1. A Structural Empirical Review (SER): Application of Neoclassical Asset Pricing Models in Sri Lanka.

\begin{tabular}{|c|c|c|c|}
\hline Code & The Model & Originators & $\begin{array}{c}\text { Number of } \\
\text { studies }\end{array}$ \\
\hline $\mathrm{CA}-$ & Capital Asset Pricing Model (CAPM) & Sharpe (1964); Lintner (1965); & 13 \\
\hline 00 & & Black (1972) & \\
\hline AP & Arbitrage Pricing Theory (APT) & Ross (1976) & 01 \\
\hline \multicolumn{4}{|l|}{00} \\
\hline $\mathrm{CC}$ & CAPM conditional on market & Pettengill et al. (1995) & 02 \\
\hline 00 & condition & & \\
\hline $\mathrm{TF}$ & Fama and French Three Factor Model & Fama \& French (1993) & 07 \\
\hline 00 & (FF3FM) & & \\
\hline MO -00 & Momentum & Jegadeesh \& Titman (1993) & 02 \\
\hline $\mathrm{CF}$ & Cahart Four Factor Model (C4FM) & Cahart (1997) & 02 \\
\hline \multicolumn{4}{|l|}{00} \\
\hline $\mathrm{FF}$ & Fama and French Five Factor & Fama \& French (2015) & 00 \\
\hline 00 & Model(FF5FM) & & \\
\hline MA -00 & $\begin{array}{l}\text { Macroeconomic variables/ asset } \\
\text { pricing }\end{array}$ & (Chen et al., 1986) & 04 \\
\hline
\end{tabular}

Source: Author

\section{Findings}

\subsection{Overview of Sri Lankan Studies}

The study includes empirical investigations of neoclassical asset pricing models in the CSE for a period of twenty years from 1997 to 2017. The empirical tests of asset pricing in Sri Lanka demonstrate that they have evolved consistently with the developments in the neoclassical literature. According to the Table 1 most of the studies during the twenty-year period from 1997 to 2017 test the SLB model and some studies use extensions to SLB model conditional to market conditions. There are studies that test atheoretical factor models such as FF3FM, C4FM in different time intervals in the CSE. However, the test of FF5FM is harder to find in the Sri Lankan market. There are studies that consider the momentum anomaly and tests of macroeconomic variables based on APT (1976) and Chen et al. (1986) framework. 
The Table 2 shows empirical investigations in the CSE that test the relationship between beta and cross section of stock returns during the period from 1997 to 2017. These studies are extended to include tests of anomalous evidence to the SLB model in the CSE such as; BE/ME, size, E/P, leverage and liquidity. The column 1 of Table 2 shows the reference of the study, column 2 depicts the time period of the study while column 3 depicts the test employed. When the earlier studies are considered, the time periods of the tests are shorter while later studies have included fifteen years or more data. These studies have employed both Fama and MacBeth (1973) and GRS test of Gibbons, Ross and Shanken (GRS) (1989) to test the models.

\subsection{Findings of Sri Lankan Studies}

Confirming existing asset pricing literature, Sri Lankan literature finds that beta as a measure of systematic risk is not consistent in explaining cross sectional variation of stock returns in the CSE. Initial studies by Samarakoon (1997) and Nimal (1997) test the SLB model together with anomalous evidence to the SLB in the CSE. These studies confirm existing literature on beta return relations while providing inconsistent findings on anomalies to the SLB model. Furthermore, the more recent studies of SLB confirm that beta cannot be used to explain cross sectional variation of returns in the CSE (Thilakarathne \& Jayasinghe, 2014). Rathnasekara (2017) finds that there is no statistically significant evidence to constitute the SLB model and raises the joint hypothesis problem where the market inefficiency may have affected the results. Therefore, it is apparent during the period of this review that beta is rejected and evidences on anomalies are inconclusive in Sri Lanka.

Fama (1998) argues that asset pricing anomalies can be made marginal or disappear by exposing them to different models or statistical approaches. Based on a similar argument Sri Lankan studies try to defend the SLB model with extensions to the model and employing different statistical approaches. As depicted in the Table 2, Anuradha (2008) investigates the conditional relations in the Sri Lankan market. The study finds that there is a significant positive (negative) relationship between beta and return in up (down) markets for both individual and portfolio of stocks. It concludes that beta cannot be rejected since it shows a significant relationship subject to the condition of the market. Nimal and Fernando (2013) defends the same argument in the continued use of beta as a measure of systematic risk in CSE. Further to find a better applicability of the SLB model in the CSE, Fernando and Nimal (2009) apply two pass OLS regression for a simulated artificial market. The study finds that two pass OLS regression approach has merely less than ten percent possibility of detecting SLB even when it exists in the market. Since power of Fama and MacBeth (1973) test is very low the study suggests that existing empirical evidence on SLB using two pass OLS in the CSE should be interpreted with caution. The study suggests more powerful tests like Gibbons, Ross, and Shanken (GRS) (1989) in making judgments on the SLB model in Sri Lanka.

In neoclassical literature the empirical evidence against the SLB model led to the development of new theoretical arguments (Ross, 1976; Chen et al., 1986) in the form of factor models to explain stock returns. The Table 3 depicts the evidence on factor models in asset pricing employed in the Sri Lankan market. Gunasekarage et al. (2004) find that the shocks to economic variables explain only a minority of the forecast variance error of the market index 
of Sri Lanka and that the affects did not persist in the long run. Menike et al. (2015) find that stock prices in Sri Lanka are sensitive to both firm level variables and changes in macroeconomic fundamentals. Furthermore, Kongahawatte and Nimal (2015)

Table 2. The Relationship between Explanatory Factors and Stock Returns in Sri Lanka 19972017

The table depicts tests of asset pricing in the Sri Lankan market from 1997 to 2017. The first column is the reference of the empirical investigation and the second is the period of the study. The methodology applied is in the third column. Then the relationship of Beta, BE/ME, Size, $\mathrm{E} / \mathrm{P}$, Leverage and Liquidity are depicted. When a specific variable is not tested in the relevant investigation it is marked (-).

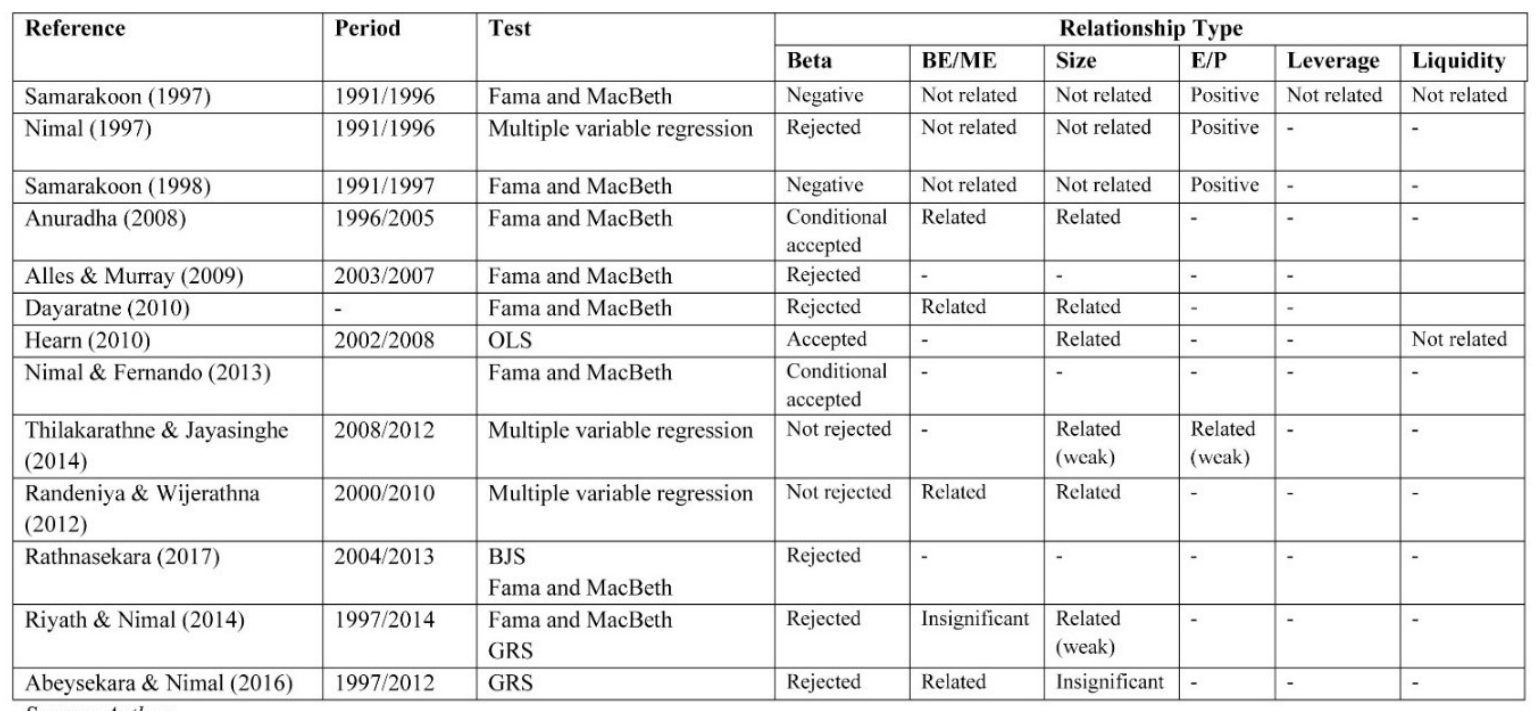

Source: Author

Study whether systematic risk factors; size and BE/ME anomalies can be subsumed through macro-economic factors in the CSE. The study finds that size and BE/ME become insignificant with the inclusion of macro factors and that the effect of macroeconomic variables are temporary in Sri Lanka unlike studies such as Chen (1986).

Atheoritical asset pricing models argue that anomalies in asset pricing can be described through parsimonious multifactor models, where the factors are chosen to fit the empirical evidence (Campbell, 2000). Table 3 shows the findings of atheoritical factor models; FF3FM (1993), C4FM (1997) and FF5FM (2015) that are empirically tested in the Sri Lankan market. Nanayakkara (2008) tests FF3FM (1993) and establishes that market, size and BE/ME factors collectively capture much of the variation of stock returns in the CSE than the single factor, beta. Senevirathna and Nimal (2009) test the economic rationale behind the FF3FM through the characteristics of size and BE/ME factors similar to the argument built by Fama and French (1995). It finds mixed evidence for the three factors when explaining company earnings and it does not find any reliable link between common risk factors in earnings and stock returns. The most crucial finding of the study is that; though the three factors capture much of the variation in returns, it is the market factor that captures most of the variation. 


\section{Macrothink}

Asian Journal of Finance \& Accounting

ISSN 1946-052X

2020, Vol. 12, No. 2

Dayaratne (2010) compares CAPM and FF3FM in predicting stock returns during the market crisis and non-crisis periods, and concludes that three factor model is a better model in capturing the variations in return during both crisis and non-crisis periods. Randeniya and Wijerathna (2012) compare CAPM and FF3FM to find whether these risk factors can capture the different characteristics of the market before and after the war in Sri Lanka. They find that small capitalisation, high BE/ME stocks tend to outperform the market, and their study suggests FF3FM is better than CAPM during the period, but the explanatory power of the model is low compared to the findings of developed markets.

In 1993 Jegadeesh and Titman find evidence of momentum where stocks that perform the best (worst) over a three to twelve months period tend to continue to perform well (poorly) over subsequent three to twelve months and that the momentum strategies are consitently profitable. Pathirawasam and Weerakoon (2008) examine the profitability of momentum strategy in the Sri Lankan context, and find that the most successful momentum strategy in CSE is selecting stocks based on their returns over the past twelve months and then holding them for next nine months. Anuradha and Nimal (2013) test momentum effect immediately and with one month lag using return for the period of twenty years with overlapping holding periods. Similar to previous findings the study concludes that stocks selected based on past twelve months return and holding them for the next six months is most profitable in CSE. These profits in the CSE initiate the momentum arguments in the Sri Lankan market whether; it is a result of market inefficiency (Campbell, 2000; Jegadeesh \& Titman, 1999), it is a product of data mining or it arise because of inherent biases in the way that investors interpret information (Barberis et al., 1998; Daniel et al., 1998). 
Table 3. Tests of Multifactor Asset Pricing models in Sri Lanka 1997-2017

The table depicts tests of multifactor asset pricing models in the Sri Lankan market during the period 1997 to 2017. The first column is the reference of the empirical investigation. Second column depicts the nature of the investigation and the third column shows the time period considered. The fourth column depicts the multifactor models/s investigated in respective studies.

\begin{tabular}{|c|c|c|c|}
\hline Reference & The Research & Period & The Factor model \\
\hline Menike (2006) & $\begin{array}{l}\text { Investigate the effects of macroeconomic variables on stock prices in } \\
\text { CSE. }\end{array}$ & $1991 / 2002$ & Chen et al., (1986) \\
\hline Nanayakkara (2008) & $\begin{array}{l}\text { Investigate whether size and BE/ME have a significant relationship in } \\
\text { explain cross section of portfolio returns in Sri Lanka. }\end{array}$ & $1998 / 2005$ & $\begin{array}{l}\text { CAPM } \\
\text { Fama \& French three factor model (1993) }\end{array}$ \\
\hline $\begin{array}{l}\text { Senavirathna \& Nimal } \\
\text { (2009) }\end{array}$ & $\begin{array}{l}\text { Investigate whether the three factor model holds in the CSE. Further } \\
\text { examine whether common factors in return mirror the common factors in } \\
\text { earnings, thus earnings are the source of corresponding factors in returns. }\end{array}$ & $1997 / 2017$ & Fama \& French three factor model (1993) \\
\hline Dayaratne (2010) & $\begin{array}{l}\text { Investigate the validity of the CAPM and the three factor model in } \\
\text { predicting stock returns during the market crisis periods and non-crisis } \\
\text { periods. }\end{array}$ & & $\begin{array}{l}\text { CAPM } \\
\text { Fama \& French three factor model (1993) }\end{array}$ \\
\hline $\begin{array}{l}\text { Randeniya \& Wijerathna } \\
(2012)\end{array}$ & $\begin{array}{l}\text { Investigate multiple factors; size, value each of which captures a different } \\
\text { characteristic of the market to improve the fit of the CAPM. }\end{array}$ & $2000 / 2010$ & $\begin{array}{l}\text { CAPM } \\
\text { Fama \& French three factor model (1993) }\end{array}$ \\
\hline Shafana et al. (2013) & $\begin{array}{l}\text { Investigate the behaviour of expected stock returns with respect to two } \\
\text { firm level characteristics: firm size and book-to-market equity in Sri } \\
\text { Lanka. }\end{array}$ & $2005 / 2010$ & $\begin{array}{l}\text { CAPM } \\
\text { Fama \& French three factor model (1993) }\end{array}$ \\
\hline Riyath \& Nimal (2014) & $\begin{array}{l}\text { Investigate a better factor model in explaining stock returns in Sri Lanka } \\
\text { from the existing asset pricing models. }\end{array}$ & $1997 / 2014$ & $\begin{array}{l}\text { CAPM } \\
\text { Fama \& French three factor model (1993) } \\
\text { Cahart four factor model (1997) }\end{array}$ \\
\hline Menike et al. (2015) & $\begin{array}{l}\text { Examines the relationship between macroeconomic and firm-specific } \\
\text { determinants of stock returns of SriLanka and United Kingdom (UK). }\end{array}$ & $1999 / 2011$ & Chen et al., (1986) \\
\hline $\begin{array}{l}\text { Kongahawatte \& Nimal } \\
(2015)\end{array}$ & $\begin{array}{l}\text { Studies whether size and BE/ME effects are subsumed by macroeconomic } \\
\text { variables in explaining variation in stock returns in Sri Lanka. }\end{array}$ & $1998 / 2013$ & $\begin{array}{l}\text { Arbitrage Pricing Theory (1976) } \\
\text { CAPM }\end{array}$ \\
\hline $\begin{array}{l}\text { Abeysekara \& Nimal } \\
\text { (2016) }\end{array}$ & Tests multifactor models for all firms and non-financial firms in the CSE & $1998 / 2012$ & $\begin{array}{l}\text { CAPM } \\
\text { Fama \& French three factor model (1993) } \\
\text { Cahart four factor model (1997) }\end{array}$ \\
\hline
\end{tabular}

With the evidence of momentum (Jegadeesh \& Titman, 1993) anomaly, Cahart four factor model (C4FM) (1997) extends the FF3FM (1993) by adding momentum as a risk factor of return. The C4FM model finds that there is a common pattern of returns in many regions including Asia Pacific. Riyath and Nimal (2014) test the C4FM (1997) for a period of seventeen years in Sri Lanka. It is a comprehensive study that tests CAPM, FF3FM, C4FM, and reward beta model using both Fama and MacBeth (1973) and GRS (1989) for non-financial firms in Sri Lanka. The study shows an insignificant positive market factor, a BE/ME premium and a significant momentum factor. The size effect is weak which adds to the evidence that there is no persistent pattern related to size and return in CSE. Abeysekara and Nimal $(2016,2017)$ is a similar inclusive study of asset pricing models in Sri Lanka that covers a period of fourteen years, and it considers all firms and non-financial firms in the CSE. The study rejects CAPM based on GRS F-statistic and finds that there is a considerable drop in GRS values for the FF3FM and C4FM respectively. Thus both studies confirm that the CAPM does not hold in the CSE, FF3FM and C4FM has the ability to explain cross sectional variation of stock returns in the CSE, while C4FM perform marginally well than the FF3FM.

\section{Discussion}

Neoclassical asset pricing literature is a coherent body of theory rather than a disjointed collection of publications (Dimson \& Mussavian, 1999). Sri Lankan asset pricing literature has aligned with the evolution of neoclassical theory by initiating with the pioneering SLB model, and empirically investigating the milestone developments in neoclassical asset pricing tests in 
the CSE. Ryan et al. (2002) state neoclassical asset pricing has reached a very high degree of sophistication but there are many new questions and unresolved problems in the existing literature, including issues relating to its fundamental assumptions.

This review of two decades of neoclassical asset pricing tests in Sri Lanka confirms the findings in other markets. It provides evidence that the rational SLB model is not supported and that the single factor beta alone cannot capture the variation of cross section of stock returns in the CSE. These inconsistencies provide the basis for the investigations of a conditional relationship between beta and return, and Sri Lankan literature finds that beta explains stock returns based on the condition of the market (Anuradha, 2008; Nimal \& Fernando, 2013). However it is hard to find the tests of dynamic versions of the SLB model (Mayers, 1972; Merton, 1973; Breeden, 1979 ) in the CSE which relaxes the assumption of a single period mode.

Neoclassical asset pricing literature debate many reasons for the inapplicability of the SLB model in asset markets. A main argument by Campbell (2000), states that anomalies provide genuine evidence against the SLB model but not against the broader concept in which there are multiple risk fators that may explain stock returns. We find evidence for mulitfactor explanation of stock returns through factor models (Ross, 1976; Chen at al, 1986; Fama and French, 1993,1996) in the CSE. While early studies were not supportive to the factor models, the recent studies provide evidence of multiple risk factors in the CSE. However, one should be cautious when interpreting results of multifactor models in CSE since the explanatory power of the models are not as strong as the findings in developed markets.

Harvey (1995) studying emerging markets develops a debate that, asset pricing models as specified are unable to explain the cross section of expected returns, because the equities exposure to commonly used risk factors are different in these markets. Alles and Murray (2009) argue that investors in emerging and frontier markets should be concerned about both systematic and unsystematic risk than beta alone. Therefore, CSE tests can be further developed by augmenting existing neoclassical models with unique characteristics identified in the frontier markets. Models such as liquidity adjusted CAPM (LCAPM) (Acharya \& Pederesen, 2005); three moment CAPM (Kraus and Litzenberger, 1976) may perform better in the CSE.

Another argument in neoclassical literature is where Roll (1977) takes the extreme position that SLB is actually untestable, because any negative results might be due to errors in the proxy used as the market. Shanken (1987) has shown that empirical results can only be reconciled with the CAPM if the correlation of the proxy with the true market is quite high. Therefore, it highlights the inquiry whether the index in the CSE correlates to the true market in Sri Lanka. Furthermore, behavioural finance builds the contrary debate that investors are not always rational. Behavioural researchers (Shefrin, 2009; Statman, 1999;Black, 1986; DeLong et al., 1990) argue that investors form beliefs based on psychological biases and heuristics thus security prices reflect both a rational and an irrational components. The lack of support for neoclassical asset pricing tests in Sri Lanka may be caused by the behavioural component in asset prices. 


\section{Conclusion}

Neoclassical asset pricing models try to explain cross sectional variation of stock returns in asset markets, and the original model assumes that market betas can capture the total systematic variation of returns. Later empirical investigations uncovered anomalies to SLB model which led to development of augmented asset pricing theories and models. Although there are inconsistent and inconclusive evidence of neoclassical asset pricing models, it remains a strong body of knowledge that is applicable until the present (Dimson \& Mussavian, 1999). In this background, this study critically reviews two decades of neoclassical asset pricing tests in the frontier market Sri Lanka.

To select the relevant literature in the Colombo Stock Exchange (CSE) the study employs Structural Empirical Review (SER) methodology, which is a quasi-experiment that derives a conclusion from the data already published. It develops a clear selection and elimination criteria to identify relevant studies to be reviewed. Based on the criteria this study specifically compare, contrast, and critically review 23 empirical investigations on neoclassical asset pricing tests in the CSE, for a period of twenty years from the year 1997 to 2017. Confirming the existing findings the SLB model is not supported in the Sri Lankan market, while a conditional relationship between beta and returns are established. The findings of the multifactor asset pricing models are not consistent with other markets. The review finds a temporary effect of macroeconomic variables on stock returns in Sri Lanka. Though the atheoritical FF3FM was not initially supported, the longer period studies support the model. These studies suggest it is the market factor that includes multiple sources of risk, which captures much of the variation in the CSE. The recent studies conclude C4FM provides a better explanation than the SLB and the FF3FM, but the explanatory powers of these models are quiet low compared to the findings in developed markets.

Next, the review discusses the debates set forth for the inconsistencies and inconclusive evidence of neoclassical asset pricing tests, specifically in frontier markets such as CSE. Campbell (2000) argues that in asset pricing the concept of multiple risk factors prevail over a single factor asset pricing model. Harvey (1995) debates that neoclassical model as specified lack support in emerging markets, because the assets' exposure to risk factors is different. Alles and Murray (2009) highlight the unique characteristics of the emerging and frontier markets that set them apart from developed markets. The viability of using the CSE as a reflection of the true market of Sri Lanka is discussed with Shanken (1987) critique. Finally the bahavioural argument inquires whether investors in the Sri Lankan market are rational. The findings of this review supports the argument that neoclassical models should be augmented with characteristics of emerging and frontier markets to make them more applicable to Sri Lanka while being aware of the inherent limitations of neoclassical asset pricing models which may have affected the findings.

\section{References}

Abeysekera, A. P., \& Nimal, P. D. (2016). The impact of the financial sector on asset pricing tests: evidence from the Colombo Stock Exchange. Asian Journal of Finance and Accounting, 8(2), 113-125. https://doi.org/10.5296/ajfa.v8i2.10056 
Abeysekera, A. P., \& Nimal, P. D. (2017). The four factor model and stock returns: evidence from Sri Lanka. Afro-Asian Journal of Finance and Accounting, 7(1). https://doi.org/10.1504/AAJFA.2017.082924

Acharya, V. V., \& Pederesen, L. H. (2005). Asset pricing with liquidity. Journal of Financial Economics. https://doi.org/10.1016/j.jfineco.2004.06.007

Alles, L., \& Murray, L. (2009). Risk factors Sri Lankan capital mrket. Sri Lankan Journal of Management, 14(1), 34-48. https://doi.org/10.4038/sllim.v1i1.427

Anuradha, P. A. (2008). The conditional relation between beta and returns:evidence from Sri Lanka. Fifth International Conference of Business Management, University of Sri Jayewardenepura, (pp. 32-44).

Anuradha, P., \& Nimal, P. D. (2013). Momenttum in stock returns:evidence from Sri Lanka. Proceedings of the Annual Research Symposium .

Ball, R. (1978). Anomalies in relationship between securities' yields and yield surrogates. Journal of Financial Economics, 6(2-3), 103-126. https://doi.org/10.1016/0304405X(78)90026-0

Banz, R. W. (1981). The relationship between return and market value of common stocks. Journal of Financial Economics, 9, 3-18. https://doi.org/10.1016/0304-405X(81)90018-0

Barberis, N., Shleifer, A., \& Vishny, R. (1998). A model of investor sentiment. Journal of Financial Economics, 49, 307-343. https://doi.org/10.1016/S0304-405X(98)00027-0

Basu, S. (1983). The relationship between earnings yield, market value, and return for NYSE common stock: further evidence. Journal of Fiancial Economics, 12, 129-156. https://doi.org/10.1016/0304-405X(83)90031-4

Berger, D., Pukthuanthong, K., \& Yang, J. (2011). International diversification with frontier markets. Journal of Financial 227-242. https://doi.org/10.1016/j.jfineco.2011.02.009

Bhandari, L. C. (1988). Debt/equity ratio and expected common stock retrun:empirical evidence. Journal of Finance, 43, 507-528. https://doi.org/10.1111/j.15406261.1988.tb03952.x

Black, F. (1986). Noise. The Journal of Finance, 41(3), 529-543. https://doi.org/10.1111/j.1540-6261.1986.tb04513.x

Black, F., Jensen, \& Scholes. (1972). The capital asset pricing model; some empirical tests. New York: Praeger Publishers.

Blume, M. E. (1993). The capital asset pricing model and the CAPM Literature. AIMR Conference Proceedings (pp. 5-10). CFA Institute. https://doi.org/10.2469/dig.v35.n2.1671 
Breeden, D. T. (1979). An intertemporal asset pricing model with stochhastic consumption and investment oppertunities. Journal of Financial Economics, 7(3), 265-296. https://doi.org/10.1016/0304-405X(79)90016-3

Brown, P., \& Walter, T. (2013). The CAPM: theoritical validity, empirical intractability and practical applications. ABACUS, 49, 44-50. http://dx.doi.org/10.1111/j.14676281.2012.00383.x

Cahart, M. M. (1997). On persistence in mutual fund performance. The Journal of Finance, 57-82. https://doi.org/10.1111/j.1540-6261.1997.tb03808.x

Campbell, J. Y. (2000). Asset pricing at the millennium. The Journal of Finance, LV(4), 15151561.http://dx.doi.org/10.1111/j.1540-6261.1997.tb04826.x

Celik, S. (2012). Theoritical and Empirical Reveiw of asset pricing models:a structural synthesis. International Journal of Economics and Financial Issues, 141-178.

Chen, N., Roll, R., \& Ross, S. A. (1986). Economic forces and stock market. Journal of Business, 59(3), 383-403. https://doi.org/10.1086/296344

Daniel, K., Hirshleifer, D., \& Subrahmanyam, A. (1998). Investor psychlogy and security market under and overreaction. The Journal of Finance, 53(6), 1839-1885. https://doi.org/10.1111/0022-1082.00077

Dayaratne, D. A. (2010). Validation of asset pricing models during crisis and non crisis periods: a comparative analysis of stock markets in Sri Lanka and the US. PhD Thesis, University of Colombo.

DeLong, J., Shleifer, A., Summers , L. H., \& Waldmann, R. J. (1990). Noise trader risk in financial markets. Journal of Political Economy, 98(4), 703-38. http://dx.doi.org/10.1086/261703

Dempsey, M. (2013). The capital asset pricing model (CAPM): the history of failed revolutionary idea in finance? ABACUS, 49. https://doi.org/10.1111/j.14676281.2012.00379.x

Dimson, E., \& Mussavian, M. (1999). Three centuries of asset pricing. Joutnal of Banking and Finance, 1745-1769. https://doi.org/10.1016/S0378-4266(99)00037-0

Fabozzi, F. J., \& Francis, J. C. (1978). Beta as a random coefficient. Journal of Financial and Quantitative Analysis, 13(1), 101-116. https://doi.org/10.2307/2330525

Fama, E. F. (1970). Efficient capital Markets:A review of theory and empirical work. Journal of Finance, 25(2), 383-417. https://doi.org/10.2307/2325486

Fama, E. F., \& French, K. R. (1992a). The cross section of expected stock returns. The Journal of Finance, 47(2), 427-465. https://dx.doi.org/10.1111/j.1540-6261.1992.tb04396.x

Fama, E. F., \& French, K. R. (1993b). Common risk factors in the stocks and bonds. Journal of Finance, 33(1), 3-56. https://dx.doi.org/10.1016/0304-405X(93)90023-5 


\section{Al Macrothink}

Asian Journal of Finance \& Accounting ISSN 1946-052X 2020, Vol. 12, No. 2

French, K. R., \& Fama, E. F. (1995). Size and book-to-market factors in earnings and returns. Journal of Finance, 50(1), 131-155. https://doi.org/10.1111/j.1540-6261.1995.tb05169.x

Fama, E. F., \& French, K. R. (2015c). A five factor asset pricing model. Journal of Financial Economics, 1-22. https://doi.org/10.1016/j.jfineco.2014.10.010

Fama, E. F., \& MacBeth, J. D. (1973). Risk, return and equilibrium: empirical tests. Journal of Political Economy, 81(3). https://doi.org/10.1086/260061

Fama, E. F., \& Schwert, G. W. (1977). Human capital and capital market equilibrium. Journal of Financial Economics, 4, 95-125. https://doi.org/10.1016/0304-405X(77)90038-1

Fernando, S., \& Nimal, P. D. (2009). The power of two pass OLS test of the CAPM: simulation analysis of CSE. 4th International Conference of Management and Finance (pp. 434-442). Colombo: University of Colombo. https://doi.org/10.2139/ssrn.1590044

Gibbons, M. R., Ross, S. A., \& Shanken, J. (1989). A test of efficiency of a given protfolio. Econometrica, 57(5), 1121-1152. https://doi.org/10.2307/1913625

Gunasekarage, A., Pisedtasalasai, A., \& Power, D. M. (2004). Macroeconomic influence on the stock market: evidence from an emerging market in South Asia. Journal of Emerging Market Finance, 3(3), 285-305. https://doi.org/10.1177/097265270400300304

Harvey, C. R. (1995). Predictable risk and returns in emerging markets. The Review of Financial Studies, 773-816. https://doi.org/10.1093/rfs/8.3.773

Hearn, B. (2010). Time varying size and liquidity effects in south asian equity markets: a study of blue-chip industry stocks. International Review of Financial Analysis, 19(4), 242-257. https://dx.doi.org/10.1016/j.irfa.2010.08.007

Jegadeesh, N., \& Titman, S. (1993a). Return to buying winners and selling losers:implication for stock market efficiency. The Journal of Finance, 48(1), 65-91. https://dx.doi.org/10.1111/j.1540-6261.1993.tb04702.x

Jegadeesh, N., \& Titman, S. (1999b). Profitability of momentum strategies: an evaluation of alternative explanations. Working paper, National Bureau of Economic Research, Cambridge. https://doi.org/10.3386/w7159

Jesson, J., \& Lacey, F. (2006). How to do (or not to do) a critical literature review . Pharmacy Education, 6(2), 139-148. https://doi.org/10.1080/15602210600616218

Kahn, K. S., Kunz, R., Kleijnen, R., \& Antes, J. (2003). Systematic reviews to support evidence based medicine. Oxford: Oxford University Press. https://doi.org/10.1002/bjs.4475

Kongahawatte, S. D., \& Nimal, P. D. (2015). Impact of macroeconomic variables on size and book to market effects in stock returns; evidence from Sri Lanka. 12th International Conference on Business management. Colombo: ICBM, USJP.

Kraus, A., \& Litzenberger, R. H. (1976). Skewness preference and the valuation of risk assets. Journal of Finance, 31(4), 1085-1100. https://doi.org/10.2307/2326275 
Lintner, J. (1965). The valuation of risk assets and the selection of risky investments in stock portfolios and capital budgets. Review of Economics and Statistics, 47, 13-37. https://doi.org/10.2307/1924119

Markowitz, H. (1952). Portfolio selection. The Journal of Finance, 77-91. https://doi.org/10.1111/j.1540-6261.1952.tb01525.x

Mayers, D. (1972). Nonmarketable assets and capital market equlibrium under uncertainty. In Studies in theory of capital markets (pp. 223-248). New York: Praeger.

Mehrling, P. (2007). Fisher Black and the revolutionary idea of Finance. New Jersy: John Wiley and Sons.

Menike, L. M., Dunusinghe, P. M., \& Ranasinghe, A. (2015). Macroeconomic and firm specific determinents of stock returns: a comparative analysis of stock markets in Sri Lanka and in the United Kingdom. Journal of Finance and Accounting, 3(4), 86-96. https://doi.org/10.11648/j.jfa.20150304.14

Merton, R. C. (1973). An Intertemporal Capital Asset Pricing Model. Econometrica, 867-887. https://doi.org/10.2307/1913811

Nanayakkara, N. S. (2008). Three factor asset pricing model: explaining cross section of stock returns in Sri Lanka. International Coference in Business Management 2008. Colombo: USJP.

Nimal, P. D. (1997). Relationship between stock returns and selected fundamental variables: Evidence from Sri Lanka. Sri Lanka Journal of Management, 2(3).

Nimal, P., \& Fernando, S. (2013). The conditional relation between beta and returns:evidence from Japan and Sri Lanka. The Hikone Ronso, 395, 94-116.

Novy - Marx, R. (2013). The other side of value: The gross profitability premium. Journal of Financial Economics, 1-28. https://doi.org/10.1016/j.jfineco.2013.01.003

Pathirawasam, C., \& Weerakoon Banda, Y. K. (2008). Profitability of momentum and contrarian strategies in the Colombo Stock Exchange. The Fifth International Conference on Business Management (pp. 27-31). Colombo: FMSC, University of Sri Jayewardenepura.

Pettengill, N. G., Sundaram, S., \& Mathur, I. (1995). The conditional relation between beta and returns. The Journal of financial And Quantitative Analysis, 30(1), 101-116. https://doi.org/10.2307/2331255

Randeniya, R., \& Wijerathna, J. K. (2012). The application of the Fama and French model for Sri Lankan Stock Market. Annual Research Symposium 2012 University of Coombol . Colombo: University of Colombo.

Rathnasekara, R. D. (2017). Testing stock market efficience and the asset pricing model:some evidence from Sri Lanka. The Journal of Developing Areas, 51(4), 317-330. https://doi.org/10.1353/jda.2017.0104 
Riyath, M. I., \& Nimal, P. D. (2014). Comparative study on asset pricing models in explaining cross sectional variation of stock returns in the Colombo Stock Exchange.

Roll, R. (1977). A critique of the asset pricing theory's testspart 1:On past and potential testability of theory. Journal of Financial Economics, 4(2), 129-176. ttps://doi.org/10.1016/0304-405X(77)90009-5

Rosenberg, B., Reid, K., \& Lanstein, R. (1984). Persuvasive evidence of market efficiency. Journal of Portfolio Management, 9-17. https://doi.org/10.3905/jpm.1985.409007

Ross, S. A. (1976). The arbitrage theory of capital asset pricing. Journal of Economic Theory, 13, 341-360. https://doi.org/10.1016/0022-0531(76)90046-6

Ryan, B., Scapens, R., \& Theobald, M. (2002). Research Method and Methodology in Finance and Accounting. South Western.

Samarakoon, L. P. (1997). The cross section of expected stock returns in Sri Lanka. Sri Lanka Journal of Management, 233-246.

Samarakoon, L. P. (1998 (Revised Nov 2009)). An empirical analysis of the relationship between fundamentals and stock returns in Sri Lanka. Research Monograph.

Senevirathna, S. M., \& Nimal, P. D. (2009). Size and book to market factors in explaining equity returns and earnings: evidence from Sri Lanka. 4th International Conference of Management and Finance (pp. 458-466). University of Colombo.

Shafana, M. A., Rimziya, A. F., \& Jariya, A. I. (2013). Reltionship between stock returns and firm size and book to market equity:empirical evidence from selected companies listed on Milanka Price index in Colombo Stock Exchange. ournal of Emerging Trends and Management Sciences, 4(2), 217-225.

Shanken, J. (1987). Multivariate proxies and asset pricing relations: Living with the Roll critique. Journal of Financial Economics, 91-110. https://doi.org/10.1016/0304405X(87)90062-6

Sharpe, W. (1964). Capital asset prices: a theory of market equilibrium under conditions of risk. Journal of Finance(19). https://doi.org/10.1111/j.1540-6261.1964.tb02865.x

Shefrin, H. (2009). Behavioralizing Finance. Foundation and Trends in Finance, 4(1-2), pp. 1184. https://doi.org/10.1561/0500000030

Statman, M. (1999). Behavioral finance: Past battles and future engagements. Financial Analysts Journal, 18-27. https://doi.org/10.2469/faj.v55.n6.2311

Stattman, D. (1980). Book value and stock returns. A Journal of Selected Papers, 4, 25-45.

Thilakarathne, P. M., \& Jayasinghe, Y. N. (2014). Validity of beta in explaining expected returns of securities listed in the Colombo stock exchange, Sri Lanka. Journal of Financing and Accounting, 2(4), 95-100. https://doi.org/10.11648/j.jfa.20140204.12 
Titman, S., Wei, K., \& Xie, F. (2004). Capital investments and stock returns. Journal of Financial and Quantitative Analysis, 677-700. https://doi.org/10.1017/S0022109000003173

BIBLIOGRAPHY Tobin, J. (1958). Estimation of relationships for limited dependent variables. Econometrica, 26, 24-36. https://doi.org/10.2307/1907382 